\title{
THE EARLIEST NORMAN SHERIFFS
}

The shire reeve (scirgerefa) is a little known figure in Anglo-Saxon England, though the names of some sheriffs can be learnt from writs addressed to shire courts, which will often address the sheriff by name but without title after the bishop and earl. In Anglo-Norman England the position of sheriff became a very important one, but its rise was not immediate. Between 1066 and 1086 an assessment can be made for each shire how the office has evolved. ${ }^{1}$ What this paper will argue is that the very words used to refer to sheriffs in a few documents from 1068 and 1069 can reveal hitherto unrecognized facts to show how Norman ideas about sheriffs changed during those first years in England.

It is well known that the Norman Conquest marked a distinct watershed in the terminology used in royal charters. Where the Latin of England had used $d u x$ for earl, in Normandy that was already used for the duke, a title of higher rank, and so Latin comes was used instead for earls in England as well as for counts in Normandy. ${ }^{2}$ The English rank of thegn had long been expressed in Latin diplomas as minister, the distinct role of cynges pegen as minister regis, 'king's thegn', but this too was rejected by the writers of King William's charters. The rank of thegn was equated with the French word baron, 'worthy man', and as a body of men barones occupy the space once occupied by thegns in the address-clauses of writ-charters, while baro regis is the nearest expression to the later usage tenant-in-chief. We cannot assume that these changes represent intentional Latin-Latin substitutions. Old English eorl was rendered as conte in French, and comes was the equivalent Latin word for the French. After the Conquest the new terminology is used with sufficient consistency that it must be considered official, though outside royal documents the language is often varied according to the taste of the writer. ${ }^{3}$ While $d u x$ continued to be used in a wide range of senses, in official contexts it was only used with reference to the position of duke, most often in the royal title dux Normannorum and later $d u x$ Normannorum et Aquitanorum. The word minister acquired a new

\footnotetext{
* My thanks to Stephen Baxter and Hugh Doherty for inspiring conversation and comments.

${ }^{1}$ R. P. Abels, 'Sheriffs, lord-seeking, and the Norman settlement of the south-east Midlands', Anglo-Norman Studies 19 (1997), 19-50 (at pp. 35-6) contrasts the position of sheriffs in 1066 and 1086.

${ }^{2}$ For example C. P. Lewis, 'The early earls of Norman England', Anglo-Norman Studies 13 (1991), 207-223 (at p. 214); D. Crouch, The Image of Aristocracy (London, 1992), 56-7; id. 'Athelings, duces, and comites in insular societies, 800-1300', in Rank and Order. The formation of aristocratic elites in western and central Europe, 500-1500, ed. J. Peltzer (Ostfildern 2015), 117-29.

${ }^{3}$ R. Sharpe, 'Official and unofficial Latin words in eleventh- and twelfth-century England', in Latin in Medieval Britain, ed. R. K. Ashdowne \& C. White, Proceedings of the British Academy (2016).
} 
official use to mean reeve. This was imported from Normandy where minister was used for officials responsible, among other duties, for tolls, 'extranei mercatores ... theloneum ministris qui maiori burgo praeerunt apportabunt', 'foreign traders will bring their toll to the officials who have charge over the greater town' (W1/45); a writ exempting the goods of the abbey of Montebourg was addessed to all the king's ministri in Normandy (W1/209). ${ }^{4}$ In England writs carrying instructions to those whose role was to execute the king's business are routinely addressed to his sheriff and ministri 'reeves, officials'. The word is sometimes linked with the earlier usage, praepositus, 'uicecomes aut praepositus seu minister regis' (W1/128), in which I take aut as stronger than seu, 'the sheriff or the king's reeve', using synonyms for the lesser office. This changeover in terminology can be observed in some detail in the small number of surviving diplomas issued by William I in Latin in the first years after the Conquest, when for the most part royal writs and writcharters were drafted in English. This paper will focus on what they tell us about sheriffs and about the Norman perception of the office of sheriff in 1068 and 1069. This is revealed in experiments with new terminology.

Before the Conquest the shire reeve (scirgerefa) was generally overshadowed by the ealdormen, later known as earls, who were the king's officers in the shires, each holding several, in a few cases many, shires. After the Conquest, the role of earls was rapidly reduced, though King William experimented with giving great powers to an earl in a single shire. ${ }^{5}$ The language actually associated the earl, comes, with a shire, now Latinized as comitatus 'county', which in official documents replaced less transparent words such as prouincia or regio, found in preConquest diplomas. The majority of shires were left with no earl to preside alongside the bishop in the shire court, and his place was taken by the sheriff, now Latinized as uicecomes, etymologically 'earl's deputy' but in practice by analogy with the Norman visconte. His role quickly became more visible. ${ }^{6}$ Sheriffs are rarely so designated in Latin documents before the Conquest, and the words praefectus and praepositus both occur. ${ }^{7}$ With no single Latin word conventionally used before the Conquest, in this case one cannot readily discuss the

\footnotetext{
${ }^{4}$ Numbers of this form refer to the edition of William I's charters by David Bates (n. 8).

${ }^{5}$ R. Sharpe, 'The earl and his shire in Anglo-Norman England', in The Earl in Medieval Britain, ed. D. Crouch \& H. F. Doherty (Woodbridge, 2016).

6 W. A. Morris, 'The office of sheriff in the Anglo-Norman period', EHR 33 (1918), 145-75, and as incorporated into his book, The Medieval English Sheriff to 1300 (Manchester, 1927), 41-74.

${ }^{7}$ For example, in a charter dated 995 (S 883), 'Apeluuig meus praepositus in Bucingaham' (Æthelwig my sheriff in Buckingham'), and in Goscelin's Vita S. Eadgythae, 'Wiltoniensis praefectus Ailuuinus in suum abducebat ergastulum' ('Aelwine sheriff of Wiltshire took him away to his prison').
} 
terminology of office as a matter of replacing one term with another, $d u x$ with comes, minister with baro. The earliest Latin diplomas of William the Conqueror, however, provide a window on the change, interesting both for what the verbal experiments tell us about how the office was perceived and for what the associated names tell us about the filling of the shrieval office.

Four documents are relevant, all of them Latin charters of King William issued in the style of the royal diplomas of King Edward and his predecessors. Three of them date from 1068, the fourth from 1069.

First, a diploma for the church of Worcester bears the date 1067 'in primo anno regni sui' ('in the first year of his reign') (Regesta 10; W1/345). ${ }^{8}$ Since it includes the attestation of Queen Matilda, who did not come to England until after Easter 1068, it has been supposed that the attestation was added to the document or included only in the extant copy. ${ }^{9}$ This anomaly does not bring the authenticity of the act into doubt. The witnesses' names are written according to precedence in two columns after the longer subscription of the king:

$\begin{array}{lrlr}\text { Ego Mathilda regina } & \text { conscribo } & \text { Ego Aldredus } & \text { archiepiscopus conscribo } \\ \text { Ego Odo } & \text { episcopus } & \text { Ego Wlstanus } & \text { episcopus } \\ \text { Ego Ageluuinus } & \text { abbas } & \text { Ego Wlstanus } & \text { abbas } \\ \text { Ego Willelmus } & \text { dux } & \text { Ego Rocgerus } & \text { dux } \\ \text { Ego Ricardus } & \text { Scrob } & \text { Ego Urs } & \text { minister } \\ \text { Ego Osebearn } & \text { minister } & \text { Ego Rodbeard Oli } & \text { minister }\end{array}$

The left-hand column begins with Queen Matilda in parellel to Archbishop Ealdred of York on the right. The queen returned to Normandy in 1069, and Ealdred died in September of that year. The list of witnesses is short, with just two in each rank, so that absence from the document is no indication of absence from court, and there is some local bias. There are two bishops, Odo of Bayeux and Wulfstan of Worcester; then two abbots, Agelwine of Evesham and Wulfstan of Gloucester; then two earls, 'Willelmus dux', that is William fitz Osbern, earl in Herefordshire and other shires, and 'Rocgerus dux', that is Roger de Montgomery, earl in Shropshire. The last two rows are taken up by the

\footnotetext{
${ }^{8}$ Hemming's Cartulary, BL MS Cotton Tiberius A. xiii (s. xi ${ }^{\mathrm{ex}}$ ), fol. 185r-v. Calendared (in an attempted chronological sequence) by H. W. C. Davis \& R. J. Whitwell, Regesta regum Anglo-Normannorum 1066-1154 i (Oxford, 1913), 3-4 (no. 10) [abbreviated as Regesta 10]; printed (in alphabetical order by beneficiary) by D. R. Bates, The Acta of William I (10661087) (Oxford, 1998), 987-8 (no. 345) [abbreviated as W1/345]. The editors of Regesta aimed to identify names in their calendar, while Bates's identifications must be sought in his index.

${ }^{9}$ Bates, Acta of William I, 987. Attestation only happened at the time of royal approval, and we are concerned solely with the witnesses' names, so our evidence in this case dates from 1068.
} 
untitled 'Ricardus Scrob' and three ministri, 'Osebearn minister', 'Urs minister', and 'Rodbeard Oli minister'.

The last two names at the right are completely recognizable. Urse de Abetot is mentioned by William of Malmesbury as sheriff of Worcester in the year 1069; he remained sheriff of Worcester until his death in 1108; and this entry was indexed by the editor of William's charters under Urse de Abetot. ${ }^{10} \mathrm{He}$ had evidently taken the place of Cyneweard, who was still alive after $1070 .{ }^{11}$ Robert de Oili is known as castellan of Oxford from the chronicle of Abingdon abbey, and he is addressed as sheriff in the writ conferring the abbey on Adelelm, monk of Jumièges (W1/4, datable to 1071). ${ }^{12}$ It would not be unreasonable to suppose that he had very recently replaced Swawold, who was addressed as sheriff of Oxfordshire by King William in an English writ in late 1067 (W1/296). The Englishman retained a lower position as reeve, appearing in Domesday Book as 'Sauuoldus' among the king's ministri in Oxford with land-holdings that connect him to two other sheriffs. ${ }^{13}$ The diploma was not cited by W. A. Morris, despite his thoroughness in seeking sheriffs. It provides an antedating to the information recorded on these Norman sheriffs in Judith Green's English Sheriffs to 1154 (1990), the essential point of reference. From these two names it appears that minister is used to denote 'sheriff', and it follows that Osbeorn minister was also a sheriff.

In King Edward's time only one Osbern was addressed as sheriff. ${ }^{14}$ This is in the writ by which the king gave the church and see of Hereford to Queen Edith's Lotharingian chaplain, Walter (S 1102, datable to 1061), which must have been issued in Old English but survives only in an early Latin version, 'Edwardus rex saluto Haroldum comitem et Osebarnum et omnes meos ministros in Herefordensi comitatu amicabiliter' ('Edward king greet Earl Harold and Osbern and all my

\footnotetext{
${ }^{10}$ William of Malmesbury, Gesta pontificum Anglorum, III $\S 115.21$, ed. M. Winterbottom, OMT (Oxford, 2007, 384, 'Vrsus erat uicecomes Wigorniae a rege constitutus' ('Urse was appointed sheriff of Worcester by the king'); J. A. Green, English Sheriffs to 1154 (London, 1990), 87; Regesta, i. 143a; Bates, Acta of William I, 1141b.

${ }^{11}$ Regesta 106; W1/349. Comment by E. Mason, The Beauchamp Cartulary, Pipe Roll Society (1980), xlviii.

${ }^{12}$ Historia ecclesie Abbendonensis, II § 2 (W1/4), § 7, ed. J. G. H. Hudson, OMT (Oxford, 2002-7), ii. 10, 'Robertus de Oileio, et ipse prediues, castelli uero urbis Oxenefordensis oppidanus' ('Robert de Oili, an extremely rich man, was castellan of Oxford castle'). The writ names two sheriffs but not their shires, which were most likely Oxfordshire and Berkshire.

${ }^{13}$ Great Domesday Book, [ed. A. Farley] (London, 1784), fol. 160d; ed. C. Caldwell, Phillimore Domesday 14 (1978), §§58. 19, 31-4, and his land in pledge to Robert de Oili, §§ 58. 31, 33. He also held property in Oxford ( $\$$ B 10) and as a tenant of the bishop of Lincoln (§§ 6. 10 16). Some of these lands he held himself in 1066, some were held by Alwi ( $\$$ B10, $\S$ 6. 16, § 58. 32), elsewhere titled 'Aluuius uicecomes' ( $\$ 58.27$ ), and perhaps his predecessor in office (Green, English Sheriffs, 69).

${ }^{14}$ Green, English Sheriffs, 45.
} 
thegns in Herefordshire friendly'); this can be retranslated into Old English thus, 'Eadward cyng gret Harold eorl $\rceil$ Osbeorn $\rceil$ alle mine thegenas on Herfordscir' freondlice'. The writ has been translated with comes and comitatus in line with post-Conquest convention but still using minister 'thegn', either a remarkable throwback or more likely a sign that the translation was made at a very early date, possibly indeed for Bishop Walter himself. ${ }^{15}$ The name after the earl's is usually that of the sheriff, though the title may be omitted. ${ }^{16}$ Hence it appears that Osbeorn was sheriff of Herefordshire in 1061 and still in 1068. The shire borders on Worcestershire, placing him well within the local catchment for this witness list. More strikingly it tells us that a pre-Conquest Norman sheriff continued to work alongside Earl William fitz Osbern in Hereford: the sheriff served the king and not the earl. Osbeorn is a name common to England and Normandy, and it cannot be assumed that he was English. Without linking him to King Edward's sheriff, Bates proposed that 'Osbearn minister' was 'almost certainly the same person as Osbernus fitz Richard Scrob'. ${ }^{17}$ Without title Richard Scrob attested immediately above Osbern minister in our witness list, and in 1067 John of Worcester linked him to the garrison of the castle at Hereford, but he had no title of office. ${ }^{18}$ Now Osbern fitz Richard Scrob was addressed alongside Urse as sheriff of Worcestershire in a later writ for Bishop Wulfstan of Worcester (W1/348), and he sat with Bishop Geoffrey, who deputized for the king, and Urse to hear a continuing plea by Bishop Wulfstan in the shire court of Worcestershire in 1086 (W1/350). At an earlier hearing, years before, Cyneweard who had been sheriff of Worcester testified, and the other persons named were Siward diues of Shropshire, Osbern fitz Richard, and

\footnotetext{
${ }^{15}$ F. E. Harmer, Anglo-Saxon Writs (Manchester, 1952), 229-31 (no. 50). The writ is twinned with writs for Bishop Giso of Wells, nominated to his see at the same time as Walter; both came from Lorraine (John of Worcester, ed. R. R. Darlington \& P. McGurk, OMT (Oxford, 1995-8), ii. 586). Both accompanied Archbishop Ealdred and Earl Tostig to Rome in 1061 (William of Malmesbury, Gesta pontificum Anglorum, III § 115). A slightly earlier writ from Hereford (S 1101) was also translated, though in that case the Old English text was also copied. The use of minister points to a pre-Conquest date for the translation, and one may suspect that Walter had the two acts put into Latin; such a context allows for the use of comes (unofficial at that date) rather than official $d u x$.

${ }^{16}$ For example, in writs of King Edward for the church of Wells, Godwine is addressed three times by name and title (S 1111, S 1113, S 1114), once by name only (S 1112), while his successor Tofi is addressed by King Edward twice by name and title (S 1115, S 1116), and twice by name only in writs of Queen Edith (S 1240) and King Harold (S 1163). E. A. Freeman correctly inferred from the writ that the sheriff of Herefordshire at the time was Osbern (The History of the Norman Conquest of England 2nd-3rd edn (Oxford, 1870-79), ii. $352 n$ ), but he confused the careers of different men of that name.

${ }^{17}$ Bates, Acta of William I, 1109b.

${ }^{18}$ John of Worcester, iii. 4, naming 'Ricardus filius Scrob', where the Anglo-Saxon Chronicle (D), s.a. 1067, mentions the Hereford garrison. John twice makes him Scrob's son (see n. 19), but Scrob is a nickname in other sources, and an English one at that (see n. 20).
} 
Thurkill of Warwickshire, in which company it is tempting to take Osbern as the man who spoke for the shire court of Herefordshire. In Domesday Book, Osbern fitz Richard had about twenty-eight hides in Herefordshire in 1066, increased to about thirty-six hides in 1086, while his father Richard Scrob had twenty-three hides across three shires in 1066, including Richard's Castle in Herefordshire. ${ }^{19}$ Osbern's Domesday holdings in Worcestershire were held by various men in 1066, among them the king at Clifton-on-Teme and Kyre, Osbern himself at Ham or Homme Castle, and his father in several places. From this it appears that in King Edward's reign he was a person of modest substance in Herefordshire, and that most of his lands in Worcestershire and elsewhere came to him after 1066 , very likely after $1071 .{ }^{20}$ We can now add to his career the likelihood that he was sheriff towards the end of King Edward's reign and retained his office for some years afterwards. His father Richard Scrob was a Norman who had come to England in King Edward's time and was one of those allowed to remain when most were sent home in 1052. ${ }^{21}$ His nickname Scrob was acquired in England. ${ }^{22}$ The line of his descendants has long been of interest. ${ }^{23}$ Sir John Lloyd was the first to show that Osbern fitz Richard was married to Nest, daughter of King Gruffydd ap Llewelyn by Ealdgyth, Earl Alfgar's daughter, and the Worcester cartulary adds corroboration. ${ }^{24} \mathrm{He}$ was still alive after 1096 ,

${ }^{19}$ Great Domesday Book, fol. 186d; ed. F. \& C. Thorn, Phillimore Domesday 17 (1983), § 24. 1-13. Richards Castle was held by Richard in 1066 (Herefs $\S 12.1-2$ ), but in 1086 Osbern had twenty-three men there ( $\$ 24.13)$. Aggregates from C. P. Lewis, 'The French in England before the Norman Conquest', Anglo-Norman Studies 17 (1995), 123-44 (at pp. 142-3).

${ }^{20}$ C. P. Lewis, 'The Norman settlement of Herefordshire under William I', Anglo-Norman Studies 7 (1985), 195-213 (at p. 202). Lewis discusses land-holding but not the shrievalty. ${ }^{21}$ Anglo-Saxon Chronicle (CD), s.a. 1052, gives no names, but the Worcester chronicle refers by name to Richard [son of] Scrob, Alfred the king's strator, and Anfrith Ceocesfot (John of Worcester, ii. 570). J. H. Round, Feudal England (London, 1895), 320-26, made sport of E. A. Freeman's discussion of Richard Scrob in Herefordshire.

${ }^{22}$ The word has no French etymology and indeed 'Scrobbesbyrig', Shrewsbury, was notoriously hard to say for French speakers. Although once associated with Scrob as Richard's supposed parent, the placename is attested rather too early in the Anglo-Saxon Chronicle, s.a. 1006, 1016, and there is the problem as to how someone in Shropshire had a Norman son. Both placename and nickname are now derived from OE scrybb 'brushwood', ModE scrub, shrub, Frisian scrob.

${ }^{23}$ W. Dugdale, Baronage of England (London, 1675-6), i. 152-3, 453-4; R. W. Eyton, The Antiquities of Shropshire (London, 1854-60), iv. 302-312; [E. Stokes in] The Complete Peerage, 2nd edn, ix (1936), 256-66.

${ }^{24}$ J. E. Lloyd, History of Wales, ii. 369, 395-7; R. R. Darlington, The Cartulary of Worcester Cathedral Priory, Pipe Roll Society (1968), xxxiv; S. D. Baxter, The Earls of Mercia (Oxford, 2007), 300. 
when Bishop Samson of Worcester confirmed a gift, 'donationem Osberti filii Ricardi', made to the prior and monks of the cathedral church. ${ }^{25}$

From this one document we infer that out of three sheriffs named in 1068 two are Normans recently appointed, and both set to serve long periods of office, while the third was another Norman but in office since at least 1061. Our understanding of this use of minister has shed new light on Osbern's career, confirmed Robert de Oili's position, and dated Urse's appointment a year earlier than was hitherto recognized.

Second, there survives a diploma for the church of Wells, dated 1067, in the sixth indiction, by which King William restored thirty hides at Banwell to Bishop Giso (Regesta 23; W1/286). Again the date 1067 is unreliable, here probably a scribal error for 1068, which corresponds to the sixth indiction. ${ }^{26}$ Again, the queen attests, so that a date after Easter 1068 is required. An occasion close to the date of her coronation at Whitsuntide, 11 May 1068, was long since argued by E. A. Freeman. Here the many witnesses have been written out by the scribe in order of precedence. After the king and queen and the bishops and abbots, the first laymen are 'Willhelmus dux', that is Earl William fitz Osbern, 'Walpeof dux', Earl Waltheof, and 'Eadwine dux', Earl Eadwine, followed by Robert the king's brother and one Roger princeps, taken for Earl Roger de Montgomery. ${ }^{27}$ Thereafter the laymen have no titles, but among them is 'Toug minister', perhaps correctly 'Touig', now identified as Tofig, at this time still sheriff of Somerset (W1/11). ${ }^{28}$ Once again, therefore, we have minister in the new sense of sheriff next to earls still styled $d u x$. In this case the sheriff is apparently an Englishman.

Other pre-Conquest sheriffs certainly remained in office in several shires in 1067, and their names appear in the address clauses of writs in Old English. ${ }^{29}$ After Latin was adopted Swegn, sheriff of Essex, remained

\footnotetext{
${ }^{25}$ Darlington, Cartulary of Worcester Cathedral Priory, 82-3 (no. 147), and Introduction, xxxiii.

${ }^{26}$ Bates, Acta of William I, 864.

${ }^{27}$ E. A. Freeman, who associated this diploma with the Whitsuntide court in 1068 and allowed no date after summer 1068, took $d u x$ for earl, deducing from this an English draftsman, and of Roger he said 'afterwards Earl of Shrewsbury' ('An unedited charter of the Conqueror', The Saturday Review of Politics, Literature, Science, and Art 44 (No. 1149, 3 November 1877), 548-9). Roger received Shropshire only 'after the fall of Morkere' (Freeman, Norman Conquest, iv. 492). Freeman questionably inferred, 'The description of Roger of Montgomery as princeps is also English. He was a great man, but as yet he had no definite title' (p. 549a). He took Tofig minister as English use for thegn, despite his knowing that Tofig was sheriff and that other witnesses surely ranked as thegns.

${ }^{28}$ Tofi is addressed by King William in an act for wells (W1/287), preserved in Latin rather than Old English, but this is an informal translation, and the text should be dated no later than 1070 .

${ }^{29}$ Addressed in Old English writs and not in Latin ones are Brihtwi and Scewine in Dorset (W1/1), Eadward alongside Hugh de Port, the Norman sheriff in Hampshire (W1/339, 340), Edmund in Hertfordshire (W1/297), Tofig in Somerset (above), Northman in Suffolk
} 
in office, whose father Robert fitz Wimarc had come to England from Normandy with King Edward and prospered. ${ }^{30}$ Swegn was alive in 1086. ${ }^{31}$ Earnwig in Nottinghamshire may be the only English sheriff to have retained his place beyond 1070, but how long he remained in post is not apparent. ${ }^{32}$

A third document, dated to Whitsuntide 1068, in the second year of the reign, already shows a different picture. This is a diploma for the minster of St Martin le Grand in London (Regesta 22; W1/181), subscribed by forty witnesses. There are seven men who attest as comes, Earl William fitz Osbern, Robert the king's brother who was count of Mortain, the English earls Waltheof, Edwin and Morcar, and two Normans, 'Robertus comes', taken by the editors of Regesta and by Bates for Count Robert of Eu, and Earl Roger de Montgomery, who was uicecomes in Normandy by descent and earl in England. Two witnesses are styled princeps, Richard fitz Gilbert and Walter Malet, and no further laymen attest. What this designation means is far from clear. This may be the first document in which comes has replaced $d u x$, and it cannot be very long after the two previously considered. It is possibly the nearest we have after the Conquest to the simple designation 'thegn' in a witness list, but it sheds no light on sheriffs.

Finally, a diploma for the church of Exeter bears the date 1069 (Regesta 28; W1/138). The witness list is here somewhat shorter. Count Robert was taken by Bates for Count Robert of $\mathrm{Eu}$, who was with the king at Winchester in April 1069, attesting an act for the church of Saint-

(W1/38), Eadric and Bristric in Wiltshire (W1/223). Where two names appear, the first is more likely to be sheriff.

${ }^{30}$ Green, English Sheriffs, 39. He is addressed in English in W1/107 and 299, but in Latin in W1/300, probably to be dated $1070 \times 1075$. Robert was one of the three most prominent French laymen in England before 1066 (Lewis, 'The French in England', 128, 143).

${ }^{31}$ Swegn of Essex was a tenant in chief in Essex in 1086, but no longer sheriff, since under Hatfield Broad Oak there is reference to a disseisin, 'quod Suenus abstulit postquam perdidit uicecomitatum' ('which Swegn took away after he lost the shrievalty') (LDB, fol. 2v; Essex § 1. 3), and Peter de Valognes was sheriff at the time of the survey (Essex $\S 1.2$ ). None the less Swegn is addressed as sheriff in two acts for St Paul's London apparently datable to $1099 \times$ 1100 (Regesta 429a, 484a), posing an unresolved question. Green seeks to escape the problem by treating these two acts as showing the Swegn was alive in 1100 but not sheriff, but this does not work. He is ordered to act in a shrieval capacity. None the less it is highly unlikely that he returned to office after Peter de Valognes. C. R. Hart, The Early Charters of Essex. The Norman Period (Leicester, 1957), 5, 18 (nos. 77, 117), redated Regesta 429a to $1066 \times$ 1076 for the sake of Swegn, deeming the bishops' names 'late insertions', and declared Regesta 484a 'a fabrication by the canons' modelled on his no. 77, now called 'spurious'. Error or forgery may be at work.

${ }^{32} \mathrm{He}$ was addressed in Old English after Archbishop Thomas of York was appointed, 23 May 1070 (W1/276). This act served as model for what is surely a forgery in the name of William II (Regesta 335), misleadingly prolonging his tenure. In both he is named alongside the Norman Turold or Thorold of Lincoln, whose term of office is also in question for the same reason. Neither man held any land in his shire in 1086. 
Denis (W1/254), though so too was Count Robert the king's brother; 'Willhelmus comes' is Earl William fitz Osbern; 'Brient comes' is the Breton Count Brian, also at Winchester in April; the English earls Edwin and Morcar follow, and after them 'Raulfus comes', that is Earl Ralf of East Anglia. Finally there are three men styled uicecomes, William, Robert, and Roger, the earliest instance of sheriffs seen in parallel with Norman viscontes, and five men styled minister, Leofnoð, Richard, Folco, Hugh, and Ralf. What we see here is the last step in the Normanization of the wording. The word uicecomes has arrived in England. The word minister no longer means thegn or baron but reeve (gerefa) or other official (wicner); such men rarely attest, and, attesting only by forenames, they are impossible to identify. ${ }^{33}$ The three uicecomites without surnames are also hard or impossible to identify. Attempts have been made. Green suggested that William uicecomes, attesting a diploma for the church of Exeter, was William de Vauville, sheriff of Devon, who is sparingly visible in other sources. ${ }^{34}$ She identified Roger uicecomes as Roger d'Ivry, though his shire is left indeterminate between Oxfordshire and Berkshire. ${ }^{35}$ Bates's index follows her for Roger but not for William, who had, incidentally, witnessed the diploma for Wells in 1068 as William de Walvile without indication of office. Roger de Pistris may also be a contender, addressed with Robert de Oili in 1071 (W1/4). Robert uicecomes is not received by either as Robert de Oili, but that appears to be a real possibility, since we have found him already attesting in 1068 with a title interpretable as sheriff.

Evidence for who held office as sheriff at this early date is hard to find, and there can hardly be any doubt that the Worcester diploma has confirmed two known early sheriffs appointed by King William and shown that another known from King Edward's time retained his office. The three names corroborate the sense of the word minister there, and it is striking to observe its downward path. From signifying thegn in Edward's diplomas, it has moved from men of high status to men holding an important office under the Norman king but one seen as service in 1068. Very swiftly, however, the view changes. The designation uicecomes

\footnotetext{
${ }^{33}$ I see no reason to follow Bates, Acta of William I, 1091a, 1118b, in thinking that Hugh may be Hugh de Montfort or Hugh de Port and that Richard may be Richard fitz Gilbert.

${ }^{34}$ Green, English Sheriffs, 35. Willelmus de Walvile is referred to retrospectively in Domesday Book, fols. 100c, 102c (Devon $\S \S 1.15,3.32$ ). An abbreviated Norman history in BL MS Cotton Vespasian A. xviii, fols. 163r-167v (s. xii ${ }^{1}$ ), refers to Bishop Osbern of Exeter, brother of William fitz Osbern, and adds, 'Castrum Exonie tuebatur W. de Waluilla uir armis strenuus et preliis exercitatus' ('W. de Walville had watch over the castle of Exeter, a man strong in arms and experienced in battles'). Green links the name to 'Guilhelmus Gualdi' who led a troop against King Harold's sons in 1069 (Orderic, ed. M. Chibnall, OMT (Oxford, 1969-80), ii. 190).

${ }^{35}$ Green, English Sheriffs, 35, cross-referring to 69 (Oxfordshire) and from there to 26 (Berkshire).
} 
explicitly links the sheriff or shire reeve with the comitatus as deputy to the comes. It was not yet apparent in 1069 that William would leave so many shires without earls at all, which would have the result that in most shires the sheriff permanently took the earl's place. What William intended for earls is not easily seen in the evidence, and evidence on sheriffs has been lacking. The brief experiment with minister as the term before settling on uicecomes reflects his clerks' taking a view. Before the Conquest the practice, thinly exhibited in Latin diplomas, may have been to use the same word, praepositus, for both reeve and shire reeve, even though in the vernacular shire reeves and high reeves are usually distinguished from other reeves. Those who drafted these diplomas, however, quickly decided that different terms were needed to distinguish the sheriff above lesser ministri, responsible only for hundreds and for demesne estates, and to reflect their coming to recognize the high office in the shire that the shrievalty represented.

From observing very specific developments in Latin usage across just four Latin diplomas we have uncovered some important points. We can name several Norman sheriffs at an earlier date than was previously known, and we can infer that the replacement of English sheriffs with Normans was happening as early as 1067 and 1068. Men such as Osbern fitz Richard in Herefordshire and Swegn fitz Robert in Essex, sons of Normans settled in England before the Conquest, may have stayed in office somewhat later than other English sheriffs. It is striking that the evidence for King William's retention of some English earls contrasts with that for his early replacement of English sheriffs. The experiments with vocabulary reflect the Normans' seeking to understand and eventually to redefine the role of the sheriff, at first seen as one of service (minister), but soon redesignated by comparison with the Norman visconte. Some Norman sheriffs quickly learnt how to exploit the office, and in most shires they did so without having an earl over them.

The diplomas that have yielded these results pose questions of their own. Who, we must ask, composed them? All four are framed as diplomas in the Anglo-Saxon tradition, all include boundary clauses in English, and one of them is substantially bilingual (W1/181). The draftsmen were no doubt English, and there has been much debate about who wrote diplomas in the names of English kings. No such debate attaches to the writing of writs under the king's seal, in English until 1070, in Latin thereafter. The regularity of their wording is evidence that they were written by the king's clerks, and the change of language from English to Latin reflects direction, control, presumably by the king. The fact that we have been able to discuss a few Latin terms in these LatinEnglish diplomas as part of a linear progression from pre-Conquest to post-Conquest terminology shows that their English draftsmen were party 
to the evolving choices as the Norman rulers refashioned the language of official documents.

RICHARD SHARPE Faculty of History, Oxford 